\title{
Characterizing ozone production and response under different meteorological conditions in Mexico City
}

\author{
W. Lei ${ }^{1,2}$, M. Zavala ${ }^{1,2}$, B. de Foy ${ }^{1,3}$, R. Volkamer ${ }^{2,4}$, and L. T. Molina ${ }^{1,2}$ \\ ${ }^{1}$ Molina Center for Energy and the Environment, CA, USA \\ ${ }^{2}$ Department of Earth, Atmospheric and Planetary Sciences, Massachusetts Institute of Technology, MA, USA \\ ${ }^{3}$ Department of Earth and Atmospheric Sciences, Saint Louis University, MO, USA \\ ${ }^{4}$ Department of Chemistry and Biochemistry, University of Colorado at Boulder, CO, USA
}

Received: 9 May 2008 - Published in Atmos. Chem. Phys. Discuss.: 18 June 2008

Revised: 4 November 2008 - Accepted: 24 November 2008 - Published: 17 December 2008

\begin{abstract}
Photochemistry in polluted atmospheres, particularly the formation of ozone $\left(\mathrm{O}_{3}\right)$, depends not only on pollutant emissions, but also on meteorological conditions. In this study a 3-D chemical transport model CAMx was employed to investigate the $\mathrm{O}_{3}$ formation and its response to emissions reduction under three distinctively different meteorological conditions in the Mexico City Metropolitan Area during the MCMA-2003 field measurement campaign. The $\mathrm{O}_{3}$ formation characteristics and sensitivity to emissions change were found to be weakly dependent on the meteorological conditions. The evolution of $\mathrm{O}_{3}$ formation and its sensitivity to $\mathrm{NO}_{\mathrm{x}}$ and VOC levels were also examined along the photochemical plume transport pathway. The midday $\mathrm{O}_{3}$ production was found to undergo a rapid increase in a narrow range of chemical aging, while downwind plumes were characterized with low and constant $\mathrm{O}_{3}$ production, and plumes along their transport pathway were characterized by a combination of the two. The $\mathrm{O}_{3}$ formation was more VOC sensitive near the source area, but as the plume became chemically aged, $\mathrm{O}_{3}$ formation became progressively VOC insensitive and more $\mathrm{NO}_{\mathrm{x}}$ sensitive.
\end{abstract}

\section{Introduction}

The photochemistry in polluted troposphere, particularly the formation of ozone $\left(\mathrm{O}_{3}\right)$, is affected not only by the pollutant precursors and their chemical aging (Liu et al., 1987; Millford et al., 1994; Sillman, 1999), but also by meteorology (Solomon et al., 2000; Seaman 2000; Sillman, 1999 and references therein). It is well known that elevated $\mathrm{O}_{3}$

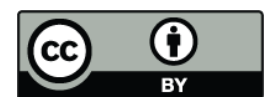

Correspondence to: L. T. Molina (ltmolina@mit.edu) episodes are often associated with warm temperatures and stagnant meteorological conditions (NRC, 1991). $\mathrm{O}_{3}$ concentrations in polluted atmosphere are affected by various meteorological parameters, such as temperature (Sillman and Samson, 1995), wind speed and vertical mixing (Sillman et al., 1995), and recirculation (Lu and Turco, 1996). Recent examples of the important links between meteorological parameters and the $\mathrm{O}_{3}$ concentration are demonstrated in modeling studies by Baertsch-Ritter et al. (2004) and Dawson et al. (2007). The $\mathrm{O}_{3}$ response to emissions of nitrogen oxides $\left(\mathrm{NO}_{\mathrm{x}}\right)$ and volatile organic compounds (VOCs), critical information in formulating air quality management policy, is also affected by meteorology. For example, more stagnant meteorology (lighter wind speed and lower mixing height) tends to shift $\mathrm{O}_{3}$ formation to the VOC-sensitive chemistry (Millford et al., 1994; Sillman et al., 1995; Sistla et al., 1996); temperature may have no direct effect on the $\mathrm{O}_{3}$ sensitivity (Sillman, 1999), but higher temperature can change the size of the VOC-or $\mathrm{NO}_{\mathrm{x}}$-limited areas (Baertsch-Ritter et al., 2004). The effects of various meteorological parameters on the $\mathrm{O}_{3}$ sensitivity chemistry in Europe have been substantiated recently by Baertsch-Ritter et al. (2004).

As the most populous city in North America, the Mexico City Metropolitan Area (MCMA) exhibits degradation of air quality experienced by many megacities around the world (Molina and Molina, 2002, 2004). The intensive and extensive MCMA-2003 field campaign was conducted in April 2003 in the MCMA to improve our understanding of air pollution in Mexico City (Molina et al., 2007). The meteorological conditions during the campaign were identified and classified into three categories: "O 3 -South", "O ${ }_{3}$-North" and "Cold Surge" by de Foy et al. (2005). These circulation patterns, shown in Fig. 1, were the results of the interaction of synoptic and local circulations. The " $\mathrm{O}_{3}$-South" episode fea-

Published by Copernicus Publications on behalf of the European Geosciences Union. 

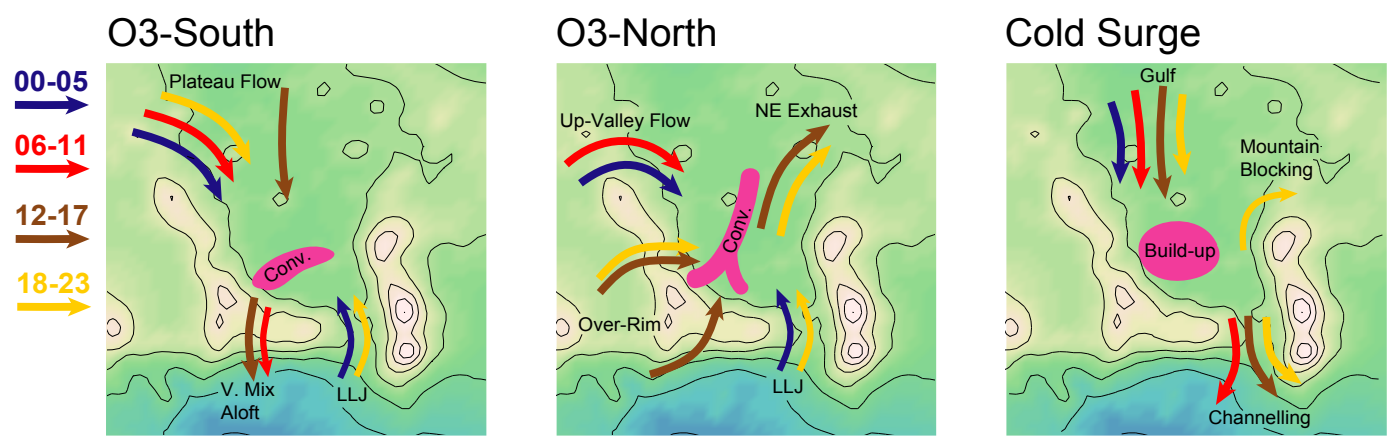

Fig. 1. Circulation model for $\mathrm{O}_{3}$-South, Cold Surge and $\mathrm{O}_{3}$-North episodes in the Mexico City basin. Arrows colored by time of day are dominant wind flows. Plateau winds on $\mathrm{O}_{3}$-South days transport the urban plume southwards of the mountains. A low level jet forms in the Chalco passage causing a convergence line in the south of the city. Strong westerly flow on $\mathrm{O}_{3}$-North days first enters the basin from the northwest but then comes over the south and west rims of the basin during the day. The combination with the low level jet forms a north-south convergence zone and exhaust of the basin to the northeast. On Cold Surge days strong northerly winds blow into the basin. Low mixing heights lead to pollutant accumulation in the city and channel flow through the Chalco passage.

tures a weak synoptic forcing associated with an anticyclone, and thermally driven circulations leads to high $\mathrm{O}_{3}$ in the south of the city; the " $\mathrm{O}_{3}$-North" episode features westerlies associated with weak anticyclone conditions to the south and a strong sub-tropical jet to the north of the MCMA, resulting in high $\mathrm{O}_{3}$ in the north of the city; the "Cold Surge" episode characterizes cold northerlies from the Gulf that brings cold humid air to the Mexico plateau, leading to cloudy sky and afternoon convection and rainfalls in the MCMA and high $\mathrm{O}_{3}$ in the city center due to stable conditions prior to the convection. These meteorological conditions also occur frequently in the MCMA in other years (de Foy et al., 2007).

Using a 3-D chemical transport model, CAMx 4.03 (Environ, 2003), we have previously examined the characteristics of photochemical $\mathrm{O}_{3}$ formation and its response to precursors in the MCMA under the "O${ }_{3}$-South" episode (Lei et al., 2007). In this study, we extend the examinations to the other two meteorological events, "O $\mathrm{O}_{3}$-North" and "Cold Surge", and compare with those obtained under the "O${ }_{3}$ South" episode. In addition, we have investigated the evolution of $\mathrm{O}_{3}$ formation and response to the emissions reduction in the urban plume. One of our goals is to investigate whether and how these characteristics (such as the $\mathrm{O}_{3}$ formation-precursor-radical relationship and the response of $\mathrm{O}_{3}$ formation to changes in emissions) change under different meteorological conditions. If the $\mathrm{NO}_{\mathrm{x}} / \mathrm{VOC}$ chemistry of $\mathrm{O}_{3}$ formation behaves consistently under different meteorological conditions, the formulation of emissions control strategies would be greatly facilitated. Another goal is to explore how the characteristics of $\mathrm{O}_{3}$ formation and its sensitivity to $\mathrm{NO}_{\mathrm{x}}$ and VOC levels evolve as the urban plume is transported downwind of the city, which has important implications for the regional air quality impacts of the urban plumes. Section 2 gives a brief description of the method. Section 3 presents the evaluation of the emission inventory, model performance, characteristics of $\mathrm{O}_{3}$ formation and its response to precursors, the chemical evolution of $\mathrm{O}_{3}$ formation and its sensitivity to emissions reduction. A summary of conclusions is provided in Sect. 4.

\section{Methodology}

The 3-D chemical transport model CAMx 4.03 (Environ, 2003) with the SAPRC-99 gas phase chemical mechanism (Carter, 2000) was employed in this study. The model domain and configuration were the same as described in Lei et al. (2007). Briefly, the model domain covers $52 \times 52$ grids with a grid resolution of $3 \mathrm{~km}$ centered in Mexico City; there are 15 vertical layers extending from the surface to about $5 \mathrm{~km}$ a.g.l. with the bottom model layer interface of about $64 \mathrm{~m}$ a.g.l. The chemical initial and boundary conditions were the same as those used in Lei et al. (2007). Photolysis rate frequencies were pre-computed with the TUV model (Madronich and Flocke, 1998) for clear sky, and were corrected for the cloud effects using the approach of Chang et al. (1987). The meteorological inputs for the model were generated by MM5 (de Foy et al., 2006). The vertical diffusivity fields $\left(k_{v}\right)$ were reconstructed from the state variables of the MM5 output using the CMAQ algorithm (Byun, 1999). de Foy et al. (2007) found that the CMAQ scheme overestimates $k_{v}$ values. Accordingly we downscaled $k_{v}$ to $20-30 \%$ based on comparison of modeled $\mathrm{CO}, \mathrm{NO}_{\mathrm{y}}$ concentrations and their ratios with observations.

The emission input fields were constructed by interpolating the official emissions inventories (EI) for the years 2002 and 2004 for the MCMA (CAM, 2004, 2006), and were adjusted based on measurements of $\mathrm{CO}, \mathrm{NO}_{\mathrm{y}}$ and speciated VOCs during the MCMA-2003 campaign (see Sect. 3.1).

In addition to the continuous measurements of a few critical pollutants by the monitoring stations of the Ambient Air Monitoring Network of Mexico City (RAMA) (SIMAT, 

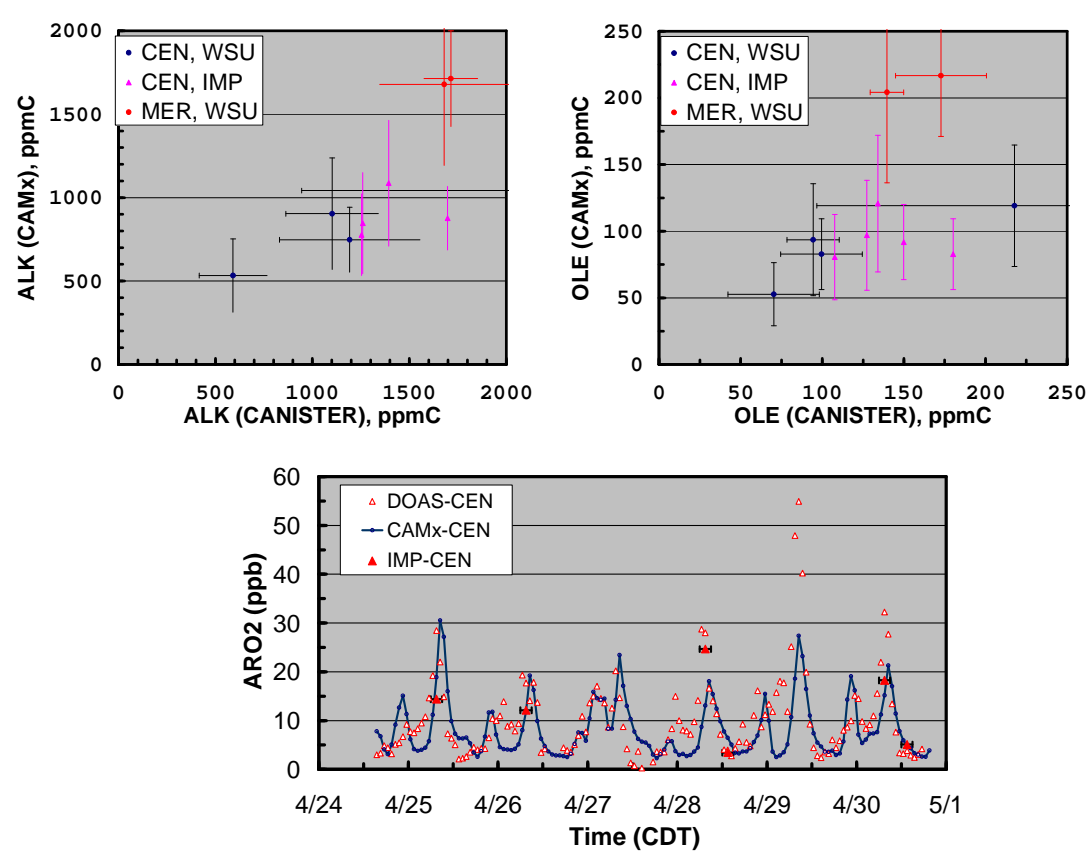

Fig. 2. Comparisons of modeled VOC concentrations with Canister (upper panel, 06:00-09:00 CDT average) and DOAS (lower panel) measurements after EI VOCs were adjusted. The error bar represents 1- $\sigma$ standard deviation.

2008), an extensive array, in terms of time, species, and measurement technique, of near ground-level measurements for speciated VOCs were made during the MCMA-2003 campaign, which included speciated VOC measurements from canister sampling analyzed by Gas Chromatography/Flame Ionization Detection (GC/FID) at various sites (Velasco et al., 2007) and long-path Differential Optical Absorption Spectroscopy (DOAS) measurements of aromatics and formaldehyde at the campaign supersite CENICA (Volkamer et al., 2005). Evaluations of the model performance and the emission inventory were carried out against these groundlevel measurements, i.e., $\mathrm{CO}, \mathrm{NO}_{\mathrm{y}}$ and $\mathrm{O}_{3}$ were compared with the RAMA data, and speciated VOCs were compared with the GC-FID and DOAS datasets. The model performance and emission evaluation will be presented in the next section.

The simulation periods selected were 8-11 April 2003, which was characterized as a "Cold Surge" episode, and 2530 April 2003, which was an "O ${ }_{3}$-North" episode (de Foy et al., 2005). Simulations started one day earlier for each period allowing $24 \mathrm{~h}$ for spin-up.

\section{Results and discussions}

\subsection{Evaluation of emission inventory}

Lei et al. (2007) evaluated the official EI for the year of 2002 using the RAMA data, VOC dataset from the canister sampling coupled with the GC/FID analysis, and the DOAS measurements at CENICA during 13-15 April 2003 (the
"O $\mathrm{O}_{3}$-South" episode). In this work, we extended the evaluation of EIs for the years 2002 and 2004 using a VOC dataset with a broader spatial (three sites) and temporal coverage (8-11 and 25-30 April). The GC/FID measurements used in this study included data obtained at CENICA, Pedregal and La Merced during the MCMA-2003 by research groups from Washington State University (WSU) and the Mexican Petroleum Institute (IMP) (Velasco et al., 2007); the aromatics and HCHO concentrations measured with DOAS covered the selected simulation periods at CENICA. The evaluation procedure is described in detail in Lei et al. (2007). In brief, first, a spatially and temporally resolved and chemically speciated initial emission estimate was constructed from the annual emissions in the official emission inventory; second, the initial emission estimate was then adjusted based on the RAMA observations of $\mathrm{CO}$ and $\mathrm{NO}_{\mathrm{y}}$ and the MCMA-2003 field measurements of speciated VOCs. Model runs with varying emission scaling factors for each gaseous primary model species were repeated and simulated, and morning rush hour (06:00-09:00 a.m.) concentrations of $\mathrm{CO}, \mathrm{NO}_{\mathrm{y}}$ and speciated VOCs were compared with measurements until a good model-measurement agreement for these species was reached. The comparisons were carried out for all primary model VOC species except higher aldehydes (CCHO and $\mathrm{RCHO}$ ) whose measurements were unavailable or incomplete.

Figure 2 gives an example of the VOC comparisons after the emissions were adjusted, which shows a good agreement between simulated and measured VOCs. Table 1 summarizes the emission adjustment factors, which shows 

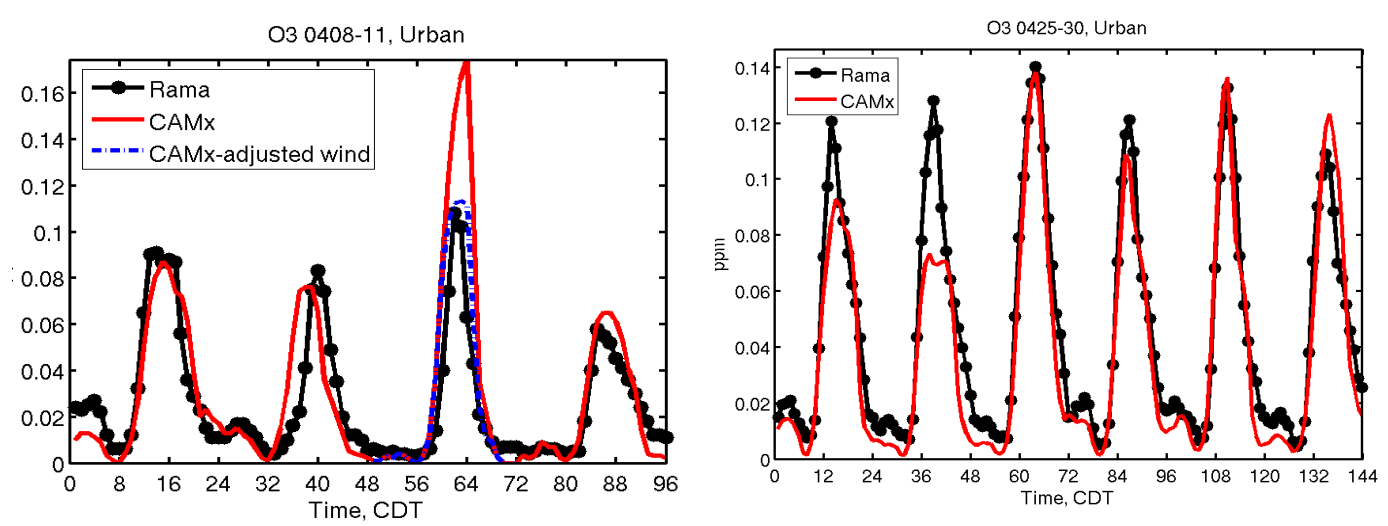

Fig. 3. Comparison of measured (black) and simulated (red) diurnal variation of near surface $\mathrm{O}_{3}$ concentrations averaged over the urban area (21 monitoring stations) during the "Cold Surge" (8-11 April, left) and the "O ${ }_{3}$-North" (25-30 April, right) episodes. Also shown in the left panel are the simulated $\mathrm{O}_{3}$ concentrations (blue dashed) on 10 April when the gap flow was enhanced by $0.5 \mathrm{~m} / \mathrm{s}$.

Table 1. Adjustment factors for correction of the MCMA emissions inventory used in this study.

\begin{tabular}{lc}
\hline CAMx Model species & Adjustment factor \\
\hline CO & 1.0 \\
NO $_{\mathrm{x}}$ & 1.0 \\
ALK1 & 2.5 \\
ALK2 & 3.0 \\
ALK3 & 4.0 \\
ALK4 & 1.2 \\
ALK5 & 0.6 \\
ETHE & 1.2 \\
OLE1 & 0.9 \\
OLE2 & 0.8 \\
ARO1 & 1.2 \\
ARO2 & 1.2 \\
HCHO & 7.0 \\
CCHO and RCHO & 4.0 \\
\hline
\end{tabular}

that the emission estimates for $\mathrm{CO}$ and $\mathrm{NO}_{\mathrm{x}}$ in the official EIs are generally accurate; the emissions of most alkanes are underestimated by about a factor of $2-4$ while the most active alkanes ( $\mathrm{C} 7$ or above, denoted as ALK5 in Table 1) are overestimated by about a factor of 2 ; emissions of alkenes are generally accurate, and the emissions of aromatics are probably slightly underestimated by $\sim 15 \%$. The overestimate of alkanes of $\mathrm{C} 7$ or above is probably an artifact due to their low concentrations, which may impose a larger uncertainty in the measurement, and also because some significant species may not be detected in the measurements. The serious underestimate of $\mathrm{HCHO}$ emissions in the MCMA are consistent with the findings of Kolb et al. (2004) and Zavala et al. (2006). An adjustment factor of 4 was assumed for higher aldehydes. The adjustment factors obtained in this study are consistent with those reported in Lei et al. (2007), given the difference in different EI years, locations where measurements were made, and the size of dataset used for comparison. The adjusted emissions were then used for the base case run.

It should be noted that even though we have broadened the dataset used for the EI evaluations, the VOC comparisons were still made over limited number of sites (CENICA, Pedregal and La Merced) and over a relatively short time period (a few weeks). A more complete EI evaluation using this approach requires more measurements with broader spatial and temporal coverage. In addition, direct evaluations of emissions using other measurement techniques (e.g., Kolb et al., 2004; Zavala et al., 2006, Velasco et al., 2007) are needed.

\subsection{Performance of $\mathrm{O}_{3}$ simulation}

Figure 3 shows the comparison of measured and simulated near-surface $\mathrm{O}_{3}$ concentrations in the MCMA urban region during 8-11 ("Cold Surge") and 25-30 ("O $\mathrm{O}_{3}$-North") April 2003. Overall the model reproduced the observations quite well except on some days, such as April 10 and 26. Figure 4 shows that on 10 April the simulated $\mathrm{O}_{3}$ was too high, perhaps because the simulated northerly component (gap flow) was too weak, leading to the over accumulation of air pollutant plume inside the basin. On 26 April, the simulated photochemical plume in the basin was shifted to the north due to overestimated SW flow (channel flow) in the morning hours, deviating far from the plume's average location and transport pathway during this episode.

A sensitivity test with an uniform increase of the gap flow by $0.5 \mathrm{~m} / \mathrm{s}$ (both the northerly and westerly components) between 10:00-17:00 CDT on 10 April dramatically improved the $\mathrm{O}_{3}$ agreement (Fig. 3); a test with a weakening of the SW channel flow on 26 April (not shown) also significantly improved the $\mathrm{O}_{3}$ agreement. de Foy et al. (2006) find that the MM5 model bias for April 2003 in the MCMA is between $-0.5-0.0 \mathrm{~m} / \mathrm{s}$ for surface winds and the variance of 


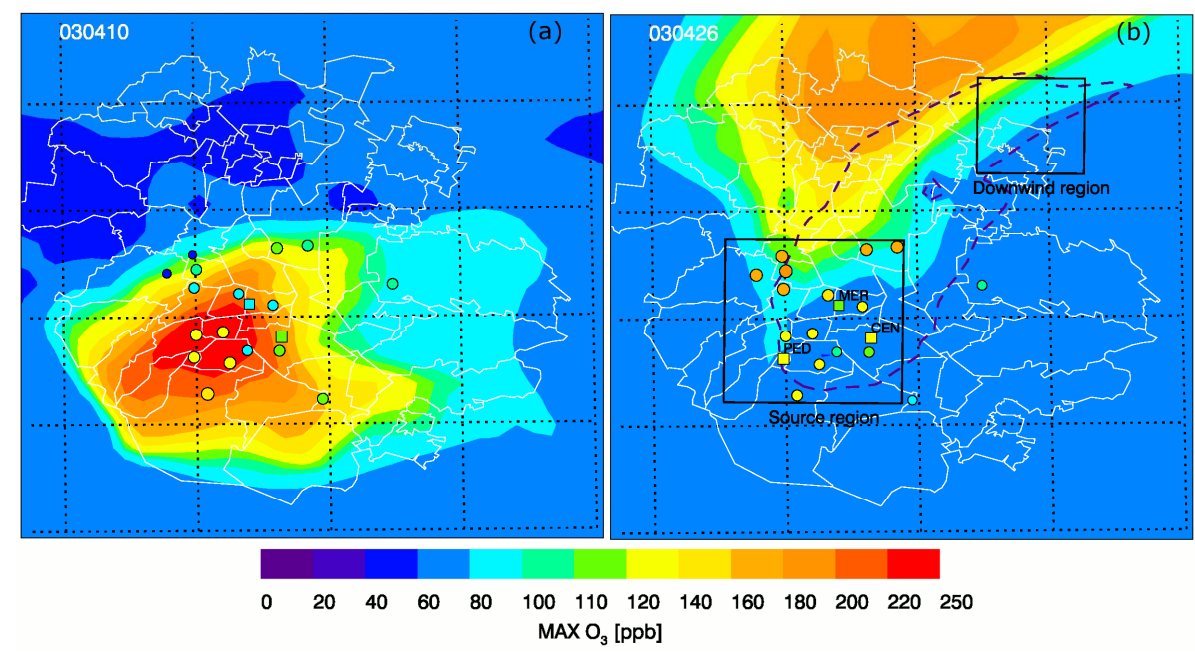

Fig. 4. Comparison of simulated (colored contour) versus observed (colored dots and squares) geographical distribution of near-surface peak $\mathrm{O}_{3}$ concentration on (a) 10 April and (b) 26 April 2003 in which the model did not perform well. The area encompassed by the dashed line in (b) is the area where peak ozone averaged over 25-30 April (except 26) 2003 exceeded 120 ppb, reflecting the plume's average location and pathway during the "O $\mathrm{O}_{3}$-North" episode. The near source area and the downwind area where the data are sampled are also delimited in (b). Also shown are the three VOC canister sampling sites.
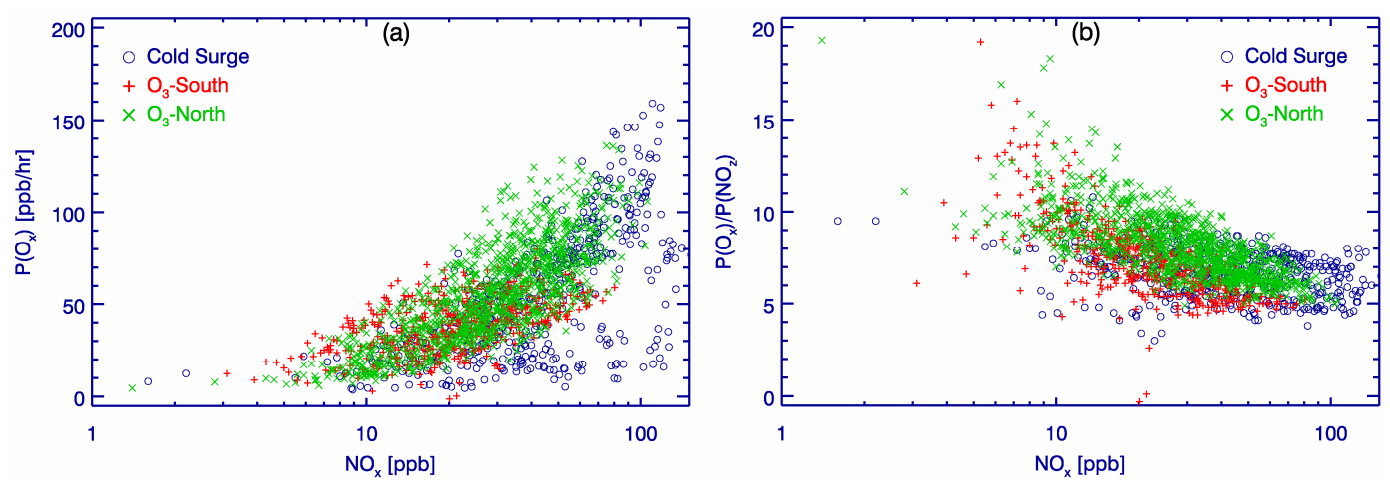

Fig. 5. Simulated midday (12:00-17:00 CDT) net $\mathrm{O}_{x}$ production rate (left) and $\mathrm{O}_{3}$ production efficiency (right) as a function of $\mathrm{NO} \mathrm{O}_{\mathrm{x}}$ concentration in the urban area of MCMA under different meteorological conditions. Data points are reduced by using every 3rd data point to avoid the high density of points.

errors is $1.0-1.5 \mathrm{~m} / \mathrm{s}$ (c.f. Fig. 5 in de Foy et al.); the model bias for the upper level winds is similar (c.f. Fig. 18 in de Foy et al.). This suggests that the wind speed modifications used in the above tests are within the model uncertainty, and it also suggests that there is room for improving the meteorological model. These results indicate that $\mathrm{O}_{3}$ concentration on the urban scale is very sensitive to the wind field, and it is essential that the chemical transport model be driven by an accurate meteorological input in the urban scale photochemical modeling. Due to the meteorological and chemical discrepancies, simulated data for 10 and 26 April will not be included for further discussion.

Table 2 summarizes the statistical performance for major gaseous pollutants in the MCMA (over 21 RAMA monitoring stations in the urban setting) during each episode (with the exclusion of 10 and 26 April). It should be noted that during the "Cold Surge" episode the surface $\mathrm{O}_{3}$ concentration was lower compared to other meteorological conditions. This is because there was a stronger daytime horizontal advection on the "Cold Surge" days. In contrast, $\mathrm{CO}$ and $\mathrm{NO}_{\mathrm{y}}$ concentrations during the Cold Surge episode were similar to those during the " $\mathrm{O}_{3}$-North" episode because the mean values of $\mathrm{CO}$ and $\mathrm{NO}_{\mathrm{y}}$ were weighted more by the concentrations at morning hours and night-time when the surface wind was generally calm for all episodes. During the " $\mathrm{O}_{3}$-South" episode (13-15 April 2003), the $\mathrm{O}_{3}$ concentration was similar to that of the "O $\mathrm{O}_{3}$-North" episode, but the primary pollutant $\left(\mathrm{CO}\right.$ and $\left.\mathrm{NO}_{\mathrm{y}}\right)$ concentrations were lower than those during other meteorological conditions, which is probably due to reduced emissions during this episode. The 
Table 2. Model statistical performance measures in the MCMA.

\begin{tabular}{|c|c|c|c|c|c|}
\hline & & & $\mathrm{O}_{3}^{*}$ & $\mathrm{CO}$ & $\mathrm{NO}_{\mathrm{y}}$ \\
\hline \multirow[t]{8}{*}{ Cold Surge } & Mean obs & $(\mathrm{ppb})$ & 27.1 & 1887 & 80.9 \\
\hline & Mean mdl & (ppb) & 26.4 & 1642 & 75.5 \\
\hline & RMSE & (ppb) & 18.9 & 1313 & 55.3 \\
\hline & IOA & & 0.88 & 0.78 & 0.80 \\
\hline & NB & $(\%)$ & -5.6 & 49.4 & 33.4 \\
\hline & NGE & $(\%)$ & 30.6 & 86.5 & 66.6 \\
\hline & NMB & $(\%)$ & -9.5 & -13.1 & -6.3 \\
\hline & AAP & $(\%)$ & 7.5 & -11.6 & -4.3 \\
\hline \multirow[t]{8}{*}{$\mathrm{O}_{3}$ South } & Mean obs & (ppb) & 47.5 & 1273 & 61.0 \\
\hline & Mean mdl & (ppb) & 42.7 & 1379 & 60.6 \\
\hline & RMSE & (ppb) & 21.6 & 925 & 43.0 \\
\hline & IOA & & 0.93 & 0.76 & 0.79 \\
\hline & NB & $(\%)$ & -1.7 & 71.5 & 30.3 \\
\hline & NGE & $(\%)$ & 24.6 & 97.2 & 63.8 \\
\hline & NMB & $(\%)$ & -1.3 & 8.2 & -1.1 \\
\hline & AAP & $(\%)$ & 8.9 & 28.6 & 10.1 \\
\hline \multirow[t]{8}{*}{$\mathrm{O}_{3}$ North } & Mean obs & (ppb) & 45.8 & 1884 & 84.2 \\
\hline & Mean mdl & (ppb) & 41.0 & 1894 & 83.8 \\
\hline & RMSE & (ppb) & 24.9 & 1277 & 58.3 \\
\hline & IOA & & 0.92 & 0.77 & 0.81 \\
\hline & NB & $(\%)$ & -5.6 & 47.9 & 36.4 \\
\hline & NGE & $(\%)$ & 28.3 & 79.3 & 68.4 \\
\hline & NMB & $(\%)$ & -5.9 & 0.6 & -0.4 \\
\hline & AAP & $(\%)$ & 3.2 & 15.0 & 2.0 \\
\hline
\end{tabular}

Obs = observation, $\mathrm{Mdl}=$ model, $\mathrm{RMSE}=$ root mean square error, IOA = index of agreement (Willmott, 1981), NB = normalized bias, $\mathrm{NGE}=$ normalized gross error, $\mathrm{NMB}=$ normalized mean bias, $\mathrm{AAP}$ $=$ average accuracy of peak paired in site.

*: in the calculation of $\mathrm{NB}, \mathrm{NGE}$ and $\mathrm{NMB}$ for $\mathrm{O}_{3}$, the threshold value for observed $\mathrm{O}_{3}$ was set to $40 \mathrm{ppb}$.

episode of 13-15 April 2003 started on Sunday followed by the Easter Week; anthropogenic emissions were reduced by 10-20\% during this episode (Lei et al., 2007) when many residents left the city for holidays. The result of similar $\mathrm{O}_{3}$ but less $\mathrm{CO}$ and $\mathrm{NO}_{\mathrm{y}}$ on weekends compared to weekdays is in agreement with the finding of a recent study of the weekend effect in the MCMA based on long-term RAMA measurements (Stephens et al., 2008).

\subsection{Characteristics of $\mathrm{O}_{3}$ production rate}

We examined the simulated net photochemical formation rates of $\mathrm{O}_{\mathrm{x}}\left(\mathrm{O}_{\mathrm{x}}=\mathrm{O}_{3}+\mathrm{NO}_{2}\right), \mathrm{P}\left(\mathrm{O}_{\mathrm{x}}\right)$, and ozone production efficiency (OPE), as a function of $\mathrm{NO}_{\mathrm{x}}$ during 8-11, 13-15, and 25-30 April; the results are presented in Fig. 5. For all three meteorological categories, generally $\mathrm{P}\left(\mathrm{O}_{\mathrm{x}}\right)$ increases with increasing $\mathrm{NO}_{\mathrm{x}}$ despite various degree of scatter. $\mathrm{P}\left(\mathrm{O}_{\mathrm{x}}\right)$ values are higher during the " $\mathrm{O}_{3}$-North" and "Cold Surge" episodes than those during the " $\mathrm{O}_{3}$-South" episode. The lower $\mathrm{P}\left(\mathrm{O}_{\mathrm{x}}\right)$ values in the " $\mathrm{O}_{3}$-South" episode are due to the reduced emissions as mentioned above, which leads to decreased VOC reactivity and radical production that will be illustrated later. The relatively high values of $\mathrm{P}\left(\mathrm{O}_{\mathrm{x}}\right)$ during the "Cold Surge" episode are probably in part due to the fact that MM5 may not completely capture the cloud effects that occurred frequently under this type of meteorological condition, which affect the air mixing (de Foy et al., 2007) and photochemical activities. Despite the high $\mathrm{P}\left(\mathrm{O}_{\mathrm{x}}\right)$ values, the $\mathrm{O}_{3}$ concentrations during the "Cold Surge" episode are lower than other meteorological conditions (see Table 2 and Fig. 3) due to the stronger advection during this event. During the "Cold Surge" event, there are many data points with high $\mathrm{NO}_{\mathrm{x}}$ but low $\mathrm{P}\left(\mathrm{O}_{\mathrm{x}}\right)$, which may be due to the imminent impacts of emissions at some locations (see Fig. $6 \mathrm{~b}$ below). The values of OPE (concentrating at 5-10 molecules of $\mathrm{O}_{3}$ per $\mathrm{NO}_{\mathrm{x}}$ oxidized) and its dependence on $\mathrm{NO}_{\mathrm{x}}$ are similar and consistent under "O $\mathrm{O}_{3}$-South", "O $\mathrm{O}_{3}$-North" and "Cold Surge" conditions, although under the "Cold Surge" condition OPE values appear to be less $\mathrm{NO}_{\mathrm{x}}$-dependent. In summary, the characteristics of $\mathrm{P}\left(\mathrm{O}_{\mathrm{x}}\right)$ and $\mathrm{OPE}$ are consistent under all meteorological conditions.

We have analyzed the relationship among $\mathrm{P}\left(\mathrm{O}_{\mathrm{x}}\right)$, VOC reactivity $\left(K_{\mathrm{VOC}}\right)$, chemical aging $\left(\mathrm{NO}_{\mathrm{z}} / \mathrm{NO}_{\mathrm{y}}\right)$, and primary radical production rate $(Q)$ in the urban area under different meteorological conditions; the results are shown in Fig. 6. The relationship between $\mathrm{P}\left(\mathrm{O}_{\mathrm{x}}\right)$ and Kvoc (Fig. 6a) is similar to that of $\mathrm{P}\left(\mathrm{O}_{\mathrm{x}}\right)-\mathrm{NO}_{\mathrm{x}}$, indicating the co-emissions of $\mathrm{NO}_{\mathrm{x}}$ and VOCs. Figure $6 \mathrm{~b}$ shows that in the "Cold Surge" event, the urban plume is fresher, with less chemical processing, which results in high $\mathrm{NO}_{\mathrm{x}}$ and VOCs, but low $\mathrm{P}\left(\mathrm{O}_{\mathrm{x}}\right)$. In the less aged air with high $\mathrm{NO}_{\mathrm{x}}$ and VOCs, the $\mathrm{O}_{3}$ concentration is lower because of titration by $\mathrm{NO}$ and radical scavenging by $\mathrm{NO}_{x}$, leading to lower radical sources from $\mathrm{O}_{3}$ photolysis and other radical precursors (such as aldehyde photolysis and alkene ozonolyis) due to slower photochemical processes. Since $\mathrm{P}\left(\mathrm{O}_{\mathrm{x}}\right)$ is strongly dependent on the radical sources (Fig. 6c), lower $Q$ values lead to lower $\mathrm{P}\left(\mathrm{O}_{\mathrm{x}}\right)$. The urban air mass is most chemically aged during the " $\mathrm{O}_{3}$-South" episode, which is understandable considering the dominant flow patterns and terrain setting. As will be discussed later, chemical aging has significant influences on the $\mathrm{NO}_{\mathrm{x}}-\mathrm{VOC}$ sensitivity of $\mathrm{O}_{3}$ formation. Over $90 \%$ of the radicals are removed through the radical- $\mathrm{NO}_{x}$ reactions (Fig. 6d) compared to less than $10 \%$ via the radical-radical reactions, implying that the midday $\mathrm{O}_{3}$ formation is VOC-limited (Sillman, 1995; Kleinman et al., 1997; Daum et al., 2000). $Q$ and $K_{\mathrm{VOC}}$ values (which are closely related to each other) are higher during the "Cold Surge" and "O ${ }_{3}$-North" episodes than during the " $\mathrm{O}_{3}$-South" episode, leading to higher $\mathrm{P}\left(\mathrm{O}_{\mathrm{x}}\right)$ values in the former. The lower $Q$ and Kvoc values during the " $\mathrm{O}_{3}$-South" episode are probably due to reduced emissions. 

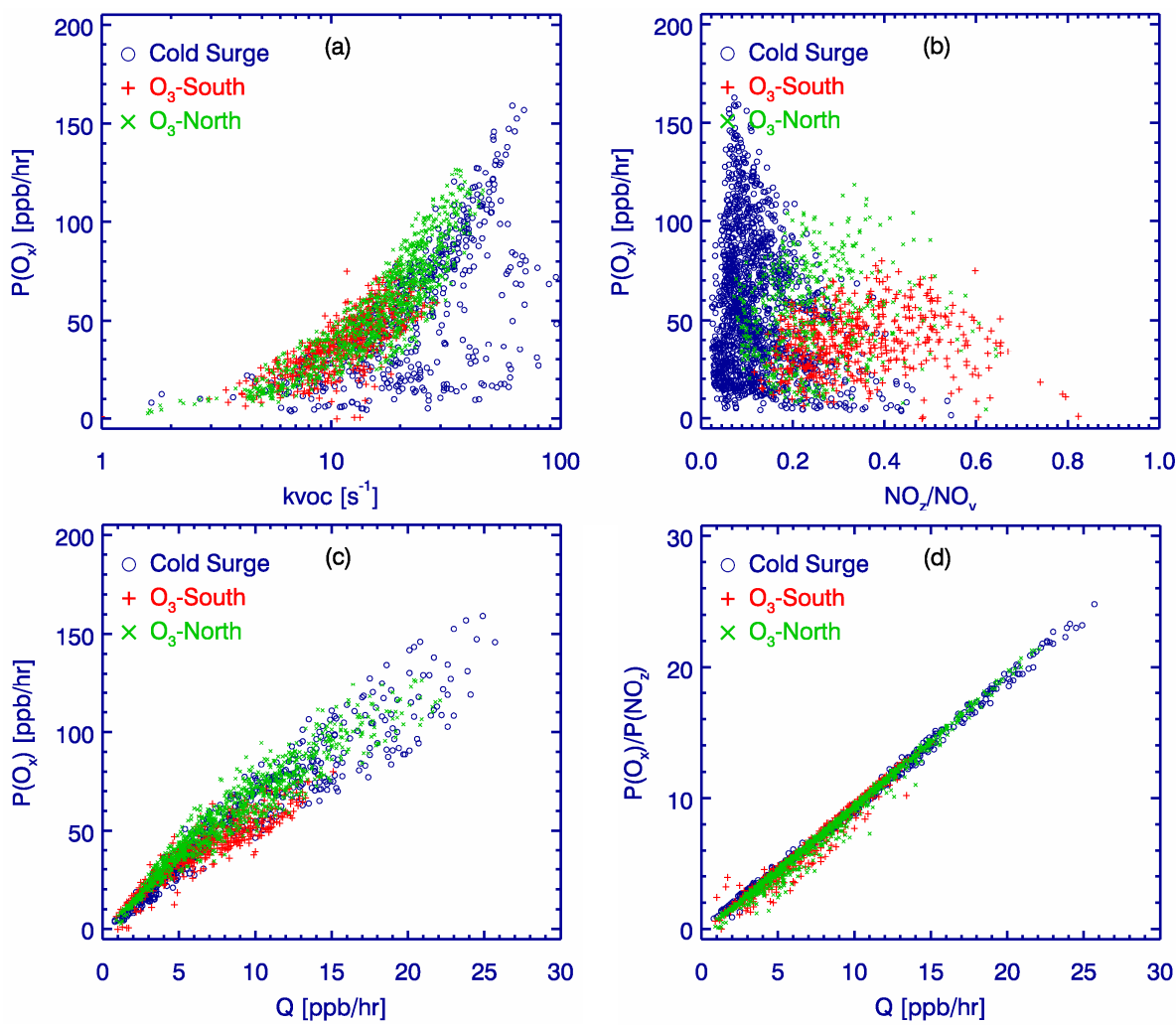

Fig. 6. Simulated relationship among $\mathrm{P}\left(\mathrm{O}_{\mathrm{x}}\right)$, VOC reactivity $\left(k_{\mathrm{VOC}}\right)$, chemical aging $\left(\mathrm{NO}_{\mathrm{z}} / \mathrm{NO}_{\mathrm{y}}\right)$ in the urban area between $12: 00-$ 17:00 CDT during different meteorological conditions. Data points are reduced by using every 3rd data point to avoid the high density of points.
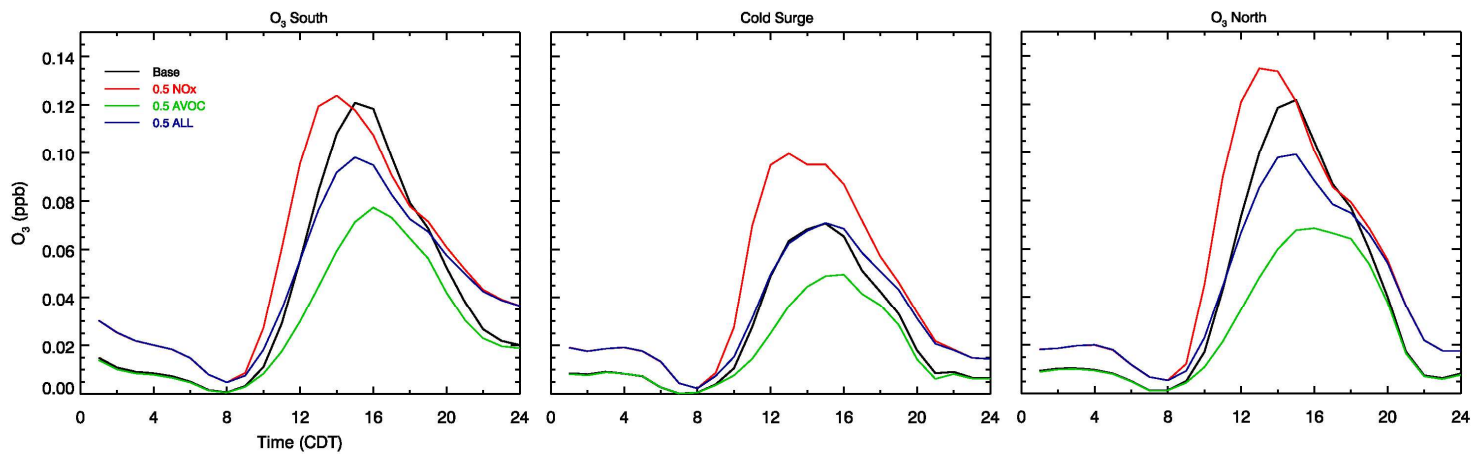

Fig. 7. Time series of surface $\mathrm{O}_{3}$ concentrations for different emission control scenarios under different meteorological conditions. Data are averaged over 8 urban representative monitoring stations and over each episode. In the legend Base denotes the base case, $0.5 \mathrm{NO}$ denotes a $50 \%$ reduction in $\mathrm{NO}_{\mathrm{x}}$ emissions, $0.5 \mathrm{VOC}$ a $50 \%$ reduction in VOC emissions, and $0.5 \mathrm{ALL}$ a $50 \%$ reduction in both $\mathrm{NO}_{\mathrm{x}}$ and $\mathrm{VOC}$ emissions.

\subsection{Response of $\mathrm{O}_{3}$ production to precursors}

We have evaluated the response of $\mathrm{O}_{3}$ formation to the $\mathrm{O}_{3}$ precursors by perturbing the emissions and examining the resulting changes in $\mathrm{O}_{3}$ concentrations and $\mathrm{O}_{3}$ production rates. The perturbations of emissions include a $50 \%$ reduction in $\mathrm{NO}_{\mathrm{x}}$ emissions only, a 50 reduction in VOC emissions only, and a 50\% reduction in both $\mathrm{NO}_{\mathrm{x}}$ and VOC emissions.
Figure 7 illustrates the effects of emission reductions on surface $\mathrm{O}_{3}$ in the urban region. It shows that a $50 \%$ reduction in $\mathrm{NO}_{\mathrm{x}}$ emissions leads to an increase in $\mathrm{O}_{3}$, while a $50 \%$ reduction in VOC emissions leads to a decrease in $\mathrm{O}_{3}$ by about a factor of 2 . In the $\mathrm{NO}_{\mathrm{x}} 50 \%$ reduction scenario, $\mathrm{O}_{3}$ increases marginally during the " $\mathrm{O}_{3}$-South" episode, but clearly increases during the other two episodes, most notably 
(a) Apr 8-11 (Cold Surge)

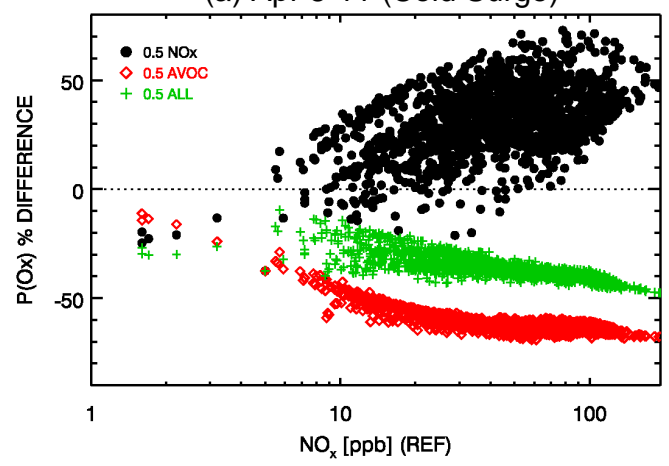

(b) Apr $25-30\left(\mathrm{O}_{3}\right.$-North)

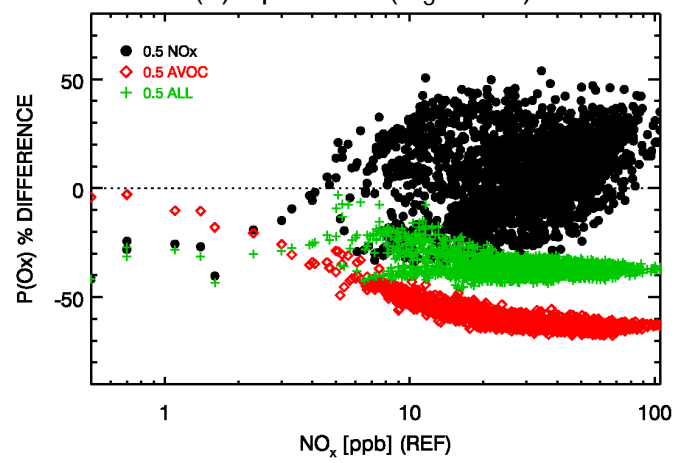

Fig. 8. The percentage change of $\mathrm{P}\left(\mathrm{O}_{\mathrm{x}}\right)$ as a function of $\mathrm{NO}_{\mathrm{x}}$ from 12:00-17:00 CDT during (a) the "Cold Surge" and (b) the "O${ }_{3}$-North" episodes in the MCMA urban region.

during the "Cold Surge" episode. This response behavior is consistent with the chemical aging of the air mass: least aged during the "Cold Surge" days, most aged during the "O $\mathrm{O}_{3}$-South" days, and the "O $\mathrm{O}_{3}$-North" days in between. Another interesting phenomenon occurs in the $50 \%$ reduction in both $\mathrm{NO}_{\mathrm{x}}$ and VOC emissions secnario. During the "O${ }_{3}$ North" episode, the surface $\mathrm{O}_{3}$ concentrations decrease as in the "O ${ }_{3}$-South" case; however, during the "Cold Surge" episode, the midday $\mathrm{O}_{3}$ does not change noticeably. This does not mean that $\mathrm{O}_{3}$ sensitivity chemistry changes during the "Cold Surge" condition compared to other meteorological conditions, as will be discussed below.

Figure 8 shows the percentage change of $\mathrm{P}\left(\mathrm{O}_{\mathrm{x}}\right)$ as a function of $\mathrm{NO}_{\mathrm{x}}$ from 12:00-17:00 CDT during the "Cold Surge" and "North-north" episodes. As in the " $\mathrm{O}_{3}$-South" case, a $50 \%$ reduction in VOCs leads to a significant decrease in $\mathrm{P}\left(\mathrm{O}_{\mathrm{x}}\right)$; a 50\% reduction in $\mathrm{NO}_{\mathrm{x}}$ leads to a decrease in $\mathrm{P}\left(\mathrm{O}_{\mathrm{x}}\right)$ at low $\mathrm{NO}_{\mathrm{x}}$ conditions but an increase in $\mathrm{P}\left(\mathrm{O}_{\mathrm{x}}\right)$ at high $\mathrm{NO}_{\mathrm{x}}$; the $50 \%$ reduction in both $\mathrm{NO}_{\mathrm{x}}$ and VOC also leads to a decrease in $\mathrm{P}\left(\mathrm{O}_{\mathrm{x}}\right)$ but less than that of the VOC-only reduction case. This is different from the change in $\mathrm{O}_{3}$ concentration showed in Fig. 7, because $\mathrm{P}\left(\mathrm{O}_{\mathrm{x}}\right)$ is more dependent on chemical cycles while $\mathrm{O}_{3}$ concentration is sensitive to both chemistry and meteorology. The inconsistency in the behaviors of $\mathrm{O}_{3}$ concentration and $\mathrm{P}\left(\mathrm{O}_{\mathrm{x}}\right)$ suggests that although meteorology may affect $\mathrm{O}_{3}$ concentrations significantly, it may not affect the rate of $\mathrm{O}_{3}$ photochemical production as much. The response of $\mathrm{P}\left(\mathrm{O}_{\mathrm{x}}\right)$ to emission reductions indicates that midday $\mathrm{O}_{3}$ formation is VOC limited in the urban region, independent of meteorological conditions.

\subsection{Evolution of photochemical plume}

In order to explore the evolution of a pollution plume as it transports pollutants downwind of the city and its impacts on the regional pollutant levels, we examined the evolution of $\mathrm{P}\left(\mathrm{O}_{\mathrm{x}}\right)$ in a pollutant plume following its pathway during the " $\mathrm{O}_{3}$-North" event. The " $\mathrm{O}_{3}$-North" event was chosen

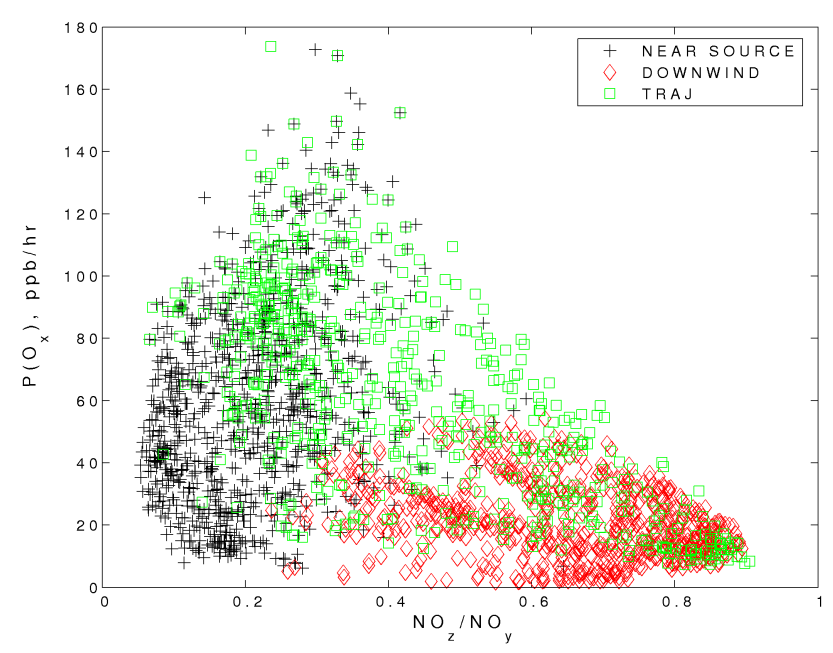

Fig. 9. Relationship between $\mathrm{P}\left(\mathrm{O}_{\mathrm{X}}\right)$ and chemical aging $\left(\mathrm{NO}_{\mathrm{Z}} / \mathrm{NO}_{\mathrm{y}}\right)$ at 12:00-17:00 CDT during 25-30 April 2003. Black dots are data sampled in the downtown near the source area, red diamonds are data sampled about $60 \mathrm{~km}$ downwind of the urban core, and green squares are data sampled along the surface plume trajectories. Data points in the near source and the downwind areas are reduced by using every 2 nd data point to avoid the high density of points.

because during this event the MCMA urban plume travels over a larger space, exerting most environmental impacts at regional scales. Figure 9 shows the evolution of $\mathrm{P}\left(\mathrm{O}_{\mathrm{x}}\right)$ in a plume with three different origins: source area, downwind area, and along the transport pathway. The source and downwind area where the data were sampled are indicated in Fig. 4b. The transport path was identified by visually tracking the location of relatively high surface $\mathrm{CO}$ concentrations coincident with high $\mathrm{O}_{3}$ concentrations each hour during 12:00-17:00 CDT every day. We observe that there are distinct relationships between $\mathrm{P}\left(\mathrm{O}_{\mathrm{x}}\right)$ and chemical aging (using $\mathrm{NO}_{\mathrm{z}} / \mathrm{NO}_{\mathrm{y}}$ as the indicator for the photochemical 


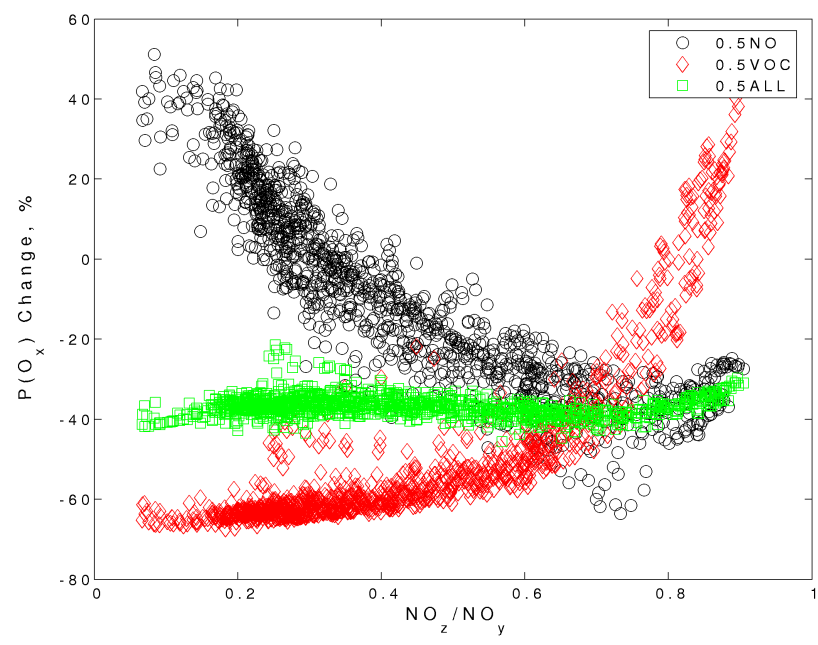

Fig. 10. Percentage change of $P\left(O_{x}\right)$ as a function of chemical aging along the plume transport pathway at 12:00-17:00 CDT during 2530 April 2003 when emissions of $\mathrm{NO}_{\mathrm{x}}$ and VOCs are reduced by $50 \%$ sequentially and simultaneously.

aging) for plumes in the urban center and in the downwind areas. Plumes in the source area are much fresher (indicated by low $\mathrm{NO}_{\mathrm{z}} / \mathrm{NO}_{\mathrm{y}}$ values); as the plumes undergo chemical processing, $\mathrm{P}\left(\mathrm{O}_{\mathrm{x}}\right)$ increases rapidly and reaches very high values within a narrow range of the chemical age parameter. On the other hand, plumes in the downwind area, about $60 \mathrm{~km}$ from the source area, are mostly highly chemically aged, and $\mathrm{P}\left(\mathrm{O}_{\mathrm{x}}\right)$ values are low and nearly constant. Plumes along the transport pathway are characterized by a combination of the signatures of fresh plumes (source area) and aged plumes (downwind), this is because as the plume is transported downwind, it becomes progressively chemically aged, even as continuous emissions along the pathway are mixed into the plume.

We also investigated the evolution of $\mathrm{O}_{3}$ formation sensitivity along the plume's transport pathway. Figure 10 shows the percentage change in $\mathrm{P}\left(\mathrm{O}_{\mathrm{x}}\right)$ as a function of chemical aging when emissions are reduced $\left(50 \%\right.$ in $\mathrm{NO}_{\mathrm{x}}$ only, $50 \%$ in VOCs only, and 50\% both) during 12:00-17:00 CDT, 25-30 April 2003. It can be seen that the $\mathrm{O}_{3}$ sensitivity changes as the plume evolves. When the plume is fresh, $\mathrm{O}_{3}$ formation is more VOC sensitive $\left(\mathrm{NO}_{\mathrm{x}}\right.$ depressed); as the plume becomes chemically aged, $\mathrm{O}_{3}$ formation becomes progressively VOC insensitive and more $\mathrm{NO}_{\mathrm{x}}$ sensitive. When the ratio of $\mathrm{NO}_{\mathrm{z}} / \mathrm{NO}_{\mathrm{y}}$ reaches 0.8 or higher, $\mathrm{O}_{3}$ formation becomes $\mathrm{NO}_{\mathrm{x}}$ sensitive. When the plume is highly aged, the VOC emission reduction tends to increase $\mathrm{P}\left(\mathrm{O}_{\mathrm{x}}\right)$. This is probably because reducing VOCs would lead to lower radical concentrations and thus lower $\mathrm{NO}_{\mathrm{z}}$ formation (through the radical- $\mathrm{NO}_{\mathrm{x}}$ reactions), which would result in higher production of $\mathrm{NO}_{2}$, even though $\mathrm{P}\left(\mathrm{O}_{3}\right)$ changes little $\left(\mathrm{O}_{\mathrm{x}}=\mathrm{O}_{3}+\mathrm{NO}_{2}\right)$.

\section{Conclusions}

We have extended the characterization of $\mathrm{O}_{3}$ formation and its response to emission reductions under " $\mathrm{O}_{3}$-South" (13-15 April 2003) meteorological condition to two more distinct episodes (8-11 April "Cold Surge" and 25-30 April "O $3_{3}$ North") using the CAMx model with an improved emission estimate evaluated with greater spatial and temporal coverage. Further, we have examined the evolution of the $\mathrm{O}_{3}$ formation and its response to emissions reduction using the " $\mathrm{O}_{3}$-North" episode as a case scenario.

The accuracy of the MCMA EI was re-evaluated using observed dataset (particularly specaited VOCs) with greater spatial and temporal coverage. The results show that the estimates of $\mathrm{CO}$ and $\mathrm{NO}_{\mathrm{x}}$ emissions in the MCMA EI are accurate, while VOCs are in general underestimated by a factor of 2-3 (1.6 overall), consistent with the study of Lei et al. (2007). However, even though a larger dataset was used for the EI evaluations, the VOC comparisons were still made over limited locations (CENICA, Pedregal and La Merced) and over a relatively short time period (a few weeks). A thorough evaluation of the EI accuracy requires more measurements with a broader spatial and temporal coverage, and measurements from other techniques such as the fleet chasing technique.

By analyzing the relationship among $\mathrm{O}_{\mathrm{x}}$ production rate $\mathrm{P}\left(\mathrm{O}_{\mathrm{x}}\right), \mathrm{O}_{3}$ precursors and radical sources, we found that the characteristics of $\mathrm{O}_{3}$ formation and its response to emission changes are weakly dependent on meteorological conditions. Under all three meteorological categories, in general midday $\mathrm{P}\left(\mathrm{O}_{\mathrm{x}}\right)$ increases with $\mathrm{NO}_{\mathrm{x}}$ with no obvious turnaround behavior, and both midday $\mathrm{P}\left(\mathrm{O}_{\mathrm{x}}\right)$ and ozone production efficiency are high at high $\mathrm{NO}_{\mathrm{x}}$ conditions compared to those in other urban cities; $\mathrm{O}_{3}$ formation is VOC limited in the MCMA urban source region as revealed by both the dependence behavior of $\mathrm{P}\left(\mathrm{O}_{\mathrm{x}}\right)$ on $\mathrm{NO}_{\mathrm{x}}$ and VOCs levels and radical production rate and the response of $\mathrm{P}\left(\mathrm{O}_{\mathrm{x}}\right)$ to precursor emission reductions.

We have also examined the evolution of $\mathrm{O}_{3}$ production and its response to emission reductions during the "O${ }_{3}$-North" event. The plumes in the source region are found to be less chemically aged, and the $\mathrm{O}_{3}$ production increases rapidly and reaches very high values within a short chemical age, while plumes in the downwind area are chemically aged and characterized by low $\mathrm{O}_{3}$ production; plumes in between are featured by the combination of fresh and aged plumes. In the fresh plume $\mathrm{O}_{3}$ formation is more VOC sensitive. As the plume becomes chemically aged, $\mathrm{O}_{3}$ formation becomes progressively VOC insensitive and more $\mathrm{NO}_{\mathrm{x}}$ sensitive.

It should be pointed out that in this study, we have covered less-than-a-week simulations for each of the three meteorological episodes. More studies are needed to comprehensively characterize the $\mathrm{O}_{3}$ formation and its response to precursors under various meteorological conditions. We plan further modeling studies using the much larger and 
comprehensive datasets from the 2006 MILAGRO (Megacity Initiative: Local and Global Research Observations) Campaign (Molina et al., 2008), in which the meteorology was characterized by 6 episode types representing different wind transport patterns (de Foy et al., 2008), in contrast to the three episode types for MCMA-2003, and where aircraft measurements provide unique opportunities for further model evaluations and interpretations and scientific explorations.

Acknowledgements. The authors gratefully acknowledge financial support from the US National Science Foundation (ATM-0528227 and ATM-0511803), Department of Energy (DE-FG02-05ER63980), and the Mexican Metropolitan Environmental Commission (CAM). The authors also acknowledge the constructive and valuable comments from the two anonymous reviewers, which helped to improve the presentation of this article. CAMx is made publicly available by ENVIRON.

Edited by: C. E. Kolb

\section{References}

Baertsch-Ritter, N., Keller, J., Dommen, J., and Prevot, A. S. H.: Effects of various meteorological conditions and spatial emissionresolutions on the ozone concentration and ROG/ $\mathrm{NO}_{\mathrm{x}}$ limitationin the Milan area (I), Atmos. Chem. Phys., 4, 423-438, 2004 , http://www.atmos-chem-phys.net/4/423/2004/.

Byun, D. W.: Dynamically consistent formulations in meteorological and air quality models for multiscale atmospheric studies Part 1: Governing equations in a generalized coordinate system, J. Atmos. Sci., 56, 3789-3807, 1999.

CAM (Comisión Ambiental Metropolitana): Inventario de Emisiones 2002 de la Zona Metropolitana del Valle de México, México, 2004.

CAM (Comisión Ambiental Metropolitana): Inventario de Emisiones 2004 de la Zona Metropolitana del Valle de México, México, 2006.

Daum, P. H., Kleinman, L. I., Imre, D. G., Nunnermacker, L. J., Lee, Y.-N.: Springston, S. R., Newman, L., and Weinstein-Lloyd, J.: Analysis of the processing of Nashville urban emissions on July 3 and July 18, 1995, J. Geophys. Res., 105, 9155-9164, 2000.

Dawson, J. P., Adam, P. J., and Pandis, S. N.: Sensitivity of ozone to summertime climate in the eastern USA: A modeling case study, Atmos. Environ., 41, 1494-1511, 2007.

de Foy, B., Caetano, E., Magaa, V., Zitcuaro, A., Cárdenas, B., Retama, A., Ramos, R., Molina, L. T., and Molina, M. J.: Mexico City basin wind circulation during the MCMA-2003 field campaign, Atmos. Chem. Phys., 5, 2267-2288, 2005, http://www.atmos-chem-phys.net/5/2267/2005/.

de Foy, B., Clappier, A., Molina, L. T., and Molina, M. J.: Distinct wind convergence patterns in the Mexico City basin due to the interaction of the gap winds with the synoptic flow, Atmos. Chem. Phys., 6, 1249-1265, 2006, http://www.atmos-chem-phys.net/6/1249/2006/.

de Foy, B., Lei, W., Zavala, M., Volkamer, R., Samuelsson, J., Mellqvist, J., Galle, B., Martínez, A.-P., Grutter, M., Retama, A., and
Molina, L. T.: Modelling constraints on the emission inventory and on vertical dispersion for $\mathrm{CO}$ and $\mathrm{SO}_{2}$ in the Mexico City Metropolitan Area using Solar FTIR and zenith sky UV spectroscopy, Atmos. Chem. Phys., 7, 781-801, 2007, http://www.atmos-chem-phys.net/7/781/2007/.

ENVIRON: User's Guide: Comprehensive Air Quality Model with Extension (CAMx) Version 4.03. ENVIRON International Corporation, Novato, California, 2003.

Kleinman, L. I., Daum, P. H., Lee, J. H., Lee, Y.-N., Nunnermacker, L. J., Springston, S. R., Newman, L., Weinstein-Lloyd, J., and Sillman, S.: Dependence of ozone production on NO and hydrocarbons in the troposphere, Geophys. Res. Lett., 24, 2299-2302, 1997.

Kolb, C. E., Herndon, S. C., McManus, J. B., Shorter, J. H., Zahniser, M. S., Nelson, D. D., Jayne, J. T., Canagaratna, M. R., and Worsnop, D. R.: Mobile laboratory with rapid response instruments for real-time measurements of urban and regional trace gas and particulate distributions and emission source characteristics, Environ. Sci. Technol., 38, 5694-5703, 2004.

Lei, W., de Foy, B., Zavala, M., Volkamer, R., and Molina, L. T.: Characterizing ozone production in the Mexico City Metropolitan Area: a case study using a chemical transport model, Atmos. Chem. Phys., 7, 1347-1366, 2007, http://www.atmos-chem-phys.net/7/1347/2007/.

Liu, S. C., Trainer, M., Fehsenfeld, F. C., Parrish, D. D., Williams, E. J., Fahey, D. W., Hubler, G., and Murphy, P. C.: Ozone production in the rural troposphere and the implications for regional and global ozone distributions, J. Geophys. Res., 92, 4191-4207, 1987.

Molina, L. T., Madronich, S., Gaffney, J. S., and Singh, H. B.: Overview of MILAGRO/INTEX-B Campaign, IGAC Newsletter, Issue No. 38, 2-15 April 2008.

Molina, L. T., Kolb, C. E., de Foy, B., Lamb, B. K., Brune, W. H., Jimenez, J. L., Ramos-Villegas, R., Sarmiento, J., ParamoFigueroa, V. H., Cardenas, B., Gutierrez-Avedoy, V., and Molina, M. J.: Air quality in North America's most populous city overview of the MCMA-2003 campaign, Atmos. Chem. Phys., 7, 2447-2473, 2007, http://www.atmos-chem-phys.net/7/2447/2007/.

Molina, L. T. and Molina, M. J. (Eds.): Air Quality in the Mexico Megacity: An Integrated Assessment, Kluwer Academy Publishers, 2002.

Molina, M. J. and Molina, L. T.: 2004 Critical Review: Megacities and Atmospheric Pollution, J. Air Manage. Assoc., 54, 644-680, 2004.

NRC (National Research Council): The effects of meteorology on tropospheric ozone, in: Rethinking the Ozone Problem in Urban and Regional Air Pollution, National Academy Press, Washington, DC, USA, 93-108, 1991.

Seaman, N. L.: Meteorological modeling for air-quality assessments, Atmos. Environ., 34, 2231-2258, 2000.

Sillman, S: The use of $\mathrm{NO}_{\mathrm{y}}, \mathrm{H}_{2} \mathrm{O}_{2}$, and $\mathrm{HNO}_{3}$ as indicators for ozone- $\mathrm{NO}_{\mathrm{X}}$-hydrocarbon sensitivity in urban locations, J. Geophys. Res., 100, 14175-14188, 1995.

Sillman, S.: The relation between ozone, $\mathrm{NO}_{\mathrm{x}}$ and hydrocarbons in urban and polluted rural environments, Atmos. Environ., 33, 1821-1845, 1999.

SIMAT, Sistema de Monitoreo Atmosferico, Ciudad de Mexico, http://www.sma.df.gob.mx/simat/, last access: 2008. 
Solomon, P., Cowling, E., Hidy, G., and Furiness, C.: Comparison of scientific findings from major ozone field studies in North America and Europe, Atmos. Environ., 34, 1885-1920, 2000.

Stephens, S., Madronich, S., Wu, F., Olson, J. B., Ramos, R., Retama, A., and Muñoz, R.: Weekly patterns of México City's surface concentrations of $\mathrm{CO}, \mathrm{NO}_{\mathrm{x}}, \mathrm{PM} 10$ and $\mathrm{O}_{3}$ during 19862007, Atmos. Chem. Phys., 8, 5313-5325, 2008, http://www.atmos-chem-phys.net/8/5313/2008/.

Velasco, E., Lamb, B., Westberg, H., Allwine, E., Sosa, G., ArriagaColina, J. L., Jobson, B. T., Alexander, M. L., Prazeller, P., Knighton, W. B., Rogers, T. M., Grutter, M., Herndon, S. C., Kolb, C. E., Zavala, M., de Foy, B., Volkamer, R., Molina, L. T., and Molina, M. J.: Distribution, magnitudes, reactivities, ratios and diurnal patterns of volatile organic compounds in the Valley of Mexico during the MCMA 2002 \& 2003 field campaigns, Atmos. Chem. Phys., 7, 329-353, 2007,

http://www.atmos-chem-phys.net/7/329/2007/.
Volkamer, R., Molina, L. T., Molina, M. J., Shirley, T., and Brune, W. H.: DOAS measurement of glyoxal as an indicator for fast VOC chemistry in urban air, Geophys. Res. Lett., 32, L08806, doi:10.1029/2005GL022616, 2005.

Willmott, C. J.: On the validation of models, Phys. Geogr., 2, 184194, 1981.

Zavala, M., Herndon, S. C., Slott, R. S., Dunlea, E. J., Marr, L. C., Shorter, J. H., Zahniser, M., Knighton, W. B., Rogers, T. M., Kolb, C. E., Molina, L. T., and Molina, M. J.: Characterization of on-road vehicle emissions in the Mexico City Metropolitan Area using a mobile laboratory in chase and fleet average measurement modes during the MCMA-2003 field campaign, Atmos. Chem. Phys., 6, 5129-5142, 2006, http://www.atmos-chem-phys.net/6/5129/2006/. 